\title{
BY-LAWS OF THE AMERICAN MATHEMATICAL SOCIETY
}

\author{
ARTICLE I \\ OFFICERS
}

Section 1. There shall be a President, a President Elect (during the evennumbered years only), an Ex-president (during the odd-numbered years only), three Vice Presidents, a Secretary, four Associate Secretaries, a Treasurer and a Librarian.

Section 2. It shall be a duty of the President to deliver an address before the Society at the close of his term of office or within one year thereafter.

Section 3. The Librarian shall have charge of arrangements for the exchange of the Society's publications.

\section{ARTICLE II}

\section{BOARD OF TRUSTEES}

Section 1. There shall be a Board of Trustees consisting of five Trustees elected by the Society in accordance with Article VII.

Section 2. The function of the Board of Trustees shall be to receive and administer the funds of the Society, to have full legal control of its investments and properties, to make contracts and, in general, to conduct all business affairs of the Society.

Section 3. The Board of Trustees shall have the power to appoint a manager and such assistants and agents as may be necessary or convenient to facilitate the conduct of the affairs of the Society, and to fix the terms and conditions of their employment. The Board may delegate to the officers of the Society duties and powers normally inhering in their respective corporative offices, subject to supervision by the Board. The Board of Trustees may appoint committees to facilitate the conduct of the financial business of the Society and delegate to such committees such powers as may be necessary or convenient for the proper exercise of those powers. Agents appointed, or members of committees designated, by the Board of Trustees need not be members of the Board.

Nothing herein contained shall be construed to empower the Board of Trustees to divest itself of responsibility for, or legal control of, the investments, properties and contracts of the Society.

\section{ARTICLE III}

\section{Editorial Committees}

Section 1. There shall be seven Editorial Committees, as follows : a committee of two members for the Bulletin; committees of three members each for the Proceedings, the Colloquium Publications, Mathematical Surveys and Mathematical Reviezes; a committee of four members jointly for the Transactions and the Memoirs, and one consisting of two representatives of the Society on the Board of Editors of the American Journal of Mathematics. 


\section{ARTICLE IV}

\section{CoUNCIL}

Section 1. The Council shall consist of fifteen members at large and the following ex officio members : the officers of the Society specified in Article I, the members of the Editorial Committees specified in Article III, any former Secretary for a period of two years following his term of office, and members of the Executive Committee who remain on the Council by the operation of Article VII, Section 4. Former Presidents and former Secretaries belonging to the Council in 1948 shall continue as members of the Council during the full terms specified in the By-Laws in effect on January 1, 1948, namely, life membership for former Secretaries who have served ten years or more and six years for former Presidents after completion of their terms of office.

Section 2. The Council shall formulate and administer the scientific policies of the Society and shall act in an advisory capacity to the Board of Trustees.

Section 3. In the absence of the Secretary from any meeting of the Council, one of the Associate Secretaries present may be designated as Acting Secretary for the meeting, either by written authorization of the Secretary, or, failing that, by majority agreement among the Associate Secretaries present.

Section 4. All members of the Council shall be voting members. The method for settling matters before the Council at any meeting shall be by majority vote of the members present. If the result of a vote is challenged, it shall be the duty of the presiding officer to determine the true vote by a roll call. In a roll call vote, each Council member shall vote only once (although he may be a member of the Council in several capacities), and he shall state before the vote in which capacity he votes. The group consisting of the four Associate Secretaries shall have one vote, and it shall be divided equally among those who vote as Associate Secretaries. Each of the six Editorial Committees shall have one vote, and it shall be divided equally among those who vote as members of the respective Editorial Committees. All other members of the Council shall have one vote each. Fractional votes shall be counted.

Section 5. Any group of members of the Council who have a total of five votes as defined in Section 4 of this Article shall constitute a quorum for the transaction of business at any meeting of the Council.

Section 6. Between meetings of the Council, business may be transacted by a mail vote. Votes shall be counted as in the case of a roll call vote as specified in Section 4 of this Article, "members present" being replaced by "members voting." An affirmative vote by mail on any proposal shall be declared if and only if (a) more than half of the total number of possible votes is received by the time announced for the closing of the polls, and (b) at least three-quarters of the votes received by then are affirmative. If members who have a total of five or more votes request postponement at the time of voting, action on the matter at issue shall be postponed until the next meeting of the Council, unless either (1) at the discretion of the Secretary, the question is made the subject of a second vote by mail, in connection with which brief statements of reasons, for and against, are circulated or (2) the Council places the matter at issue before the Executive Committee for action.

Section 7. The Council may delegate to the Executive Committee (Article V) certain of its duties and powers. Between meetings of the Council the Executive Committee shall act for the Council on such matters and in such ways as the Council 
may specify. Nothing herein contained shall be construed as empowering the Council to divest itself of responsibility for formulating and administering the scientific policies of the Society.

\section{ARTICLE V \\ EXecutive Committee}

Section 1. There shall be an Executive Committee of the Council, consisting of four elected members and the following ex officio members: the President, the Secretary, the President Elect (during even-numbered years), and the Ex-president (during odd-numbered years).

Section 2. The Executive Committee of the Council shall be empowered to act for the Council on matters which have been delegated to the Executive Committee by the Council. If three members of the Executive Committee request that any matter be referred to the Council, the matter shall be so referred. The Executive Committee shall be responsible to the Council and shall report its actions to the Council. It may consider the agenda for meetings of the Council and may make recommendations to the Council.

Section 3. Each member of the Executive Committee shall have one vote. An affirmative vote on any proposal before the Executive Committee shall be declared if and only if at least four affirmative votes are cast for the proposal. A vote on any proposal may be determined at a meeting of the Executive Committee, but it shall not be necessary to hold a meeting to determine a vote.

\section{ARTICLE VI}

\section{Executive Director}

Section 1. There shall be an Executive Director who shall be a paid employee of the Society. He shall have charge of the central office of the Society, and he shall be responsible for the general administration of the affairs of the Society in accordance with the policies that are set by the Board of Trustees and by the Council.

Section 2. The Executive Director shall be elected by the Council for a specified term and approved by the Board of Trustees. The terms and conditions of his employment shall be fixed by the Board of Trustees.

Section 3. The Executive Director shall work under the immediate direction of the Board of Trustees and of the Council, and in cooperation with the Secretary. $\mathrm{He}$ shall attend meetings of the Board of Trustees, of the Council, and of the Executive Committee, but he shall not be a member of any of these bodies.

\section{ARTICLE VII}

\section{Election ANd Terms of OfFICERS}

Section 1. The term of office shall be one year in the case of the President Elect and the Ex-president; two years in the case of the Trustees (with the exceptions stated in the next paragraph of this Section), the President, the Vice Presidents, the Secretary, the Associate Secretaries, and the Treasurer; three years in the case of the Librarian and the members of the Editorial Committees. The term of office for members at large of the Council shall be three years, five of the members at large retiring annually. The term of office for elected members of the Executive 
Committee shall be two years (with the exceptions stated in the last paragraph of this Section), two of the elected members retiring annually. In every case, however, the officials specified in Articles I, II, III, IV, and V, with the exception of the President Elect and the Ex-president, shall continue to serve until their successors have been duly elected and qualified.

The term of office in the case of the Trustees to be elected at the Annual Meeting to be held between the fifteenth of December, 1948, and the fifteenth of January, 1949 , shall be three years in the case of two of the Trustees to be elected and shall be two years in the case of three of the Trustees to be elected. Upon the expiration of the terms of office of the Trustees elected at the Annual Meeting to be held between the fifteenth of December, 1948, and the fifteenth of January, 1949, the term of office of all Trustees shall be two years.

In the case of members elected to the Executive Committee at the first election following adoption of these By-Laws the terms of office shall be one year for two of the members so elected and two years for the other two. After the expiration of the one-year terms of office, the term of office for all elected members of the Executive Committee shall be two years as specified in the first paragraph of this Section.

The initial Editorial Committee for the Proceedings shall consist of three members, chosen by the Council from the existing Editorial Committee of the Bulletin. They shall be withdrawn from the latter committee and shall complete their terms of office as members of the new committee. At the first election following adoption of this by-law, a second member shall be elected to the Editorial Committee of the Bulletin and a fourth member to the joint Editorial Committee of the Transactions, and the Memoirs.

Section 2. Election of officers specified in Article I (with the exception of the President and the Ex-president), Trustees, members of the Editorial Committees, and members at large of the Council shall be by ballot at the Annual Meeting. An official ballot shall be sent to each member of the Society by the Secretary at least one month before the Annual Meeting, and such ballots, if returned to the Secretary in envelopes bearing the name of the voter and received prior to the closing of the polls, shall be counted at the Annual Meeting. Each ballot shall contain one or more names proposed by the Council for each office to be filled, with blank spaces in which the voter may substitute other names. A plurality of all votes cast, whether cast in person or by mail, shall be necessary for election. In case of failure to secure a plurality for any office, the members present at the Annual Meeting shall choose by ballot among the members having the highest number of votes.

Section 3. At the end of his term of office, the President Elect shall become the President. At the end of his term of office, the President shall become the Expresident.

Section 4. Within fourteen days after the election of officers at the Annual Meeting the Secretary shall send to all members of the Council for a mail vote a ballot containing two names for each place to be filled on the Executive Committee. The nominees shall be chosen by a committee appointed by the President. Members of the Council may vote for persons not nominated. Any member of the Council who is not an ex officio member of the Executive Committee (see Article V, Section 1) shall be eligible for election to the Executive Committee. In case a member is elected to the Executive Committee for a term extending beyond his regular term 
on the Council, he shall automatically continue as a member of the Council during his term on the Executive Committee.

Section 5. The President and Vice Presidents shall not be eligible for immediate re-election to their respective offices. A member at large or an ex officio member of the Council shall not be eligible for immediate election (or re-election) as a member at large of the Council.

Section 6. If the President of the Society die or resign while a President Elect is in office, the President Elect shall serve as President for the remainder of the year and thereafter shall serve his regular two-year term. If the President of the Society die or resign when no President Elect is in office, the Council, with the approval of the Board of Trustees, shall designate one of the Vice Presidents to serve as President for the balance of the regular presidential term. If the President Elect of the Society die or resign before becoming President, his office shall remain vacant until the next regular election of a President Elect, and the Society shall, at the next Annual Meeting, elect a President for a two-year term. If the Expresident die or resign before the expiration of his term of office, the Council, with the approval of the Board of Trustees, shall designate a former President of the Society to serve as Ex-president during the remainder of the regular term of the Ex-presidency. Such vacancies as may occur at any time in the group consisting of the Vice Presidents, the Secretary, the Associate Secretaries, the Treasurer, the Librarian, and the members of the Editorial Committees shall be filled by the Council with the approval of the Board of Trustees. If a member of an Editorial Committee takes temporary leave from his duties, that Committee shall nominate a substitute for consideration by the Council. The Council shall then elect a substitute. The Council shall fill from its own membership any vacancy in the elected membership of the Executive Committee.

Section 7. If any Trustee die or resign during his tenure of office, the vacancy thus created shall be filled for his unexpired term by the Board of Trustees.

Section 8. If any member at large of the Council die or resign more than one year before the expiration of his term, the vacancy for the unexpired term shall be filled by the Society at the next Annual Meeting.

\section{ARTICLE VIII}

\section{Members and Their Election}

Section 1. Election of members shall be by vote of the Council or of its Executive Committee.

Section 2. There shall be three classes of members, namely, ordinary, contributing and institutional.

Section 3. Application for admission to ordinary membership shall be made by the applicant on a blank provided by the Secretary, and shall be approved either by two ordinary members of the Society or by the institutional member whose nominee he is (see Article IX, Section 6). Such applications shall not be acted upon until at least thirty days after their presentation to the Council (at a meeting or by mail), except in the case of members of other societies entering under special action of the Council approved by the Board of Trustees.

Section 4. An ordinary member may become a contributing member by paying the dues for such membership. (See Article IX, Section 3.) 
Section 5. A university or college, or a firm, corporation, or association interested in the support of mathematics may be elected an institutional member.

\section{ARTICLE IX}

\section{Dues and Privileges of Members}

Section 1. Any person elected to ordinary membership in the Society under the provisions of Article VIII, Section 3, who is not a nominee of an institutional member (See Section 6 of this Article) shall be admitted to membership upon payment, within sixty days of the date of his election, of an initiation fee of five dollars and such dues as are payable under Section 2 of this Article.

Section 2. The annual dues of a person, not a nominee of an institutional member, who is elected to ordinary membership under the provisions of Article VIII, Section 3, shall be fourteen dollars, with the following exceptions: (1) during the first and second years of membership, the annual dues shall be nine dollars; during the third and fourth years of membership, the annual dues shall be eleven dollars and fifty cents; a person shall be considered to have completed his first year of membership on January 1 following his election; (2) the amount of dues may be altered by reciprocity agreements with other societies; (3) the Council may make special rulings in exceptional cases, with the approval of the Board of Trustees. Each new member shall pay in proportion to the unexpired fraction of the year at the time of his election.

Section 3. The minimum dues for a contributing member shall be twenty dollars per year. Members may, upon their own initiative, pay larger dues.

Section 4. The minimum dues of an institutional member shall depend on the amount of published material credited to that member in certain journals during a specific period. The formula for computing these dues shall be established from time to time by the Council subject to approval by the Board of Trustees. Institutions may pay larger dues than the computed minimum.

Section 5. Any member whose annual dues are at least one hundred dollars shall be designated as a Sustainer of the Society; any member whose annual dues are at least five hundred dollars shall be designated as a Patron of the Society.

Section 6. The privileges of an institutional member shall depend on its dues in a manner to be determined by the Council, subject to approval by the Board of Trustees. These privileges shall be in terms of Society publications to be received by the institution and of the number of persons it may nominate for ordinary membership in the Society.

Section 7. A person elected to ordinary membership as a nominee of an institutional member under the provisions of Section 6 of this Article and of Article VIII, Section 3, shall be admitted to membership immediately and shall not be required to pay an initiation fee. He shall not be required to pay dues so long as it is agreed that he is designated as a nominee of the institutional member under these provitions. If a nominee of an institutional member later becomes a dues-paying member, he shall pay dues at the rate of nine dollars a year for the remainder (if any) of his first two years of membership, eleven dollars and fifty cents a year for the remainder (if any) of his third and fourth years of membership, and fourteen dollars a year thereafter.

Section 8. After retirement from active service on account of age, any ordinary 
or contributing member who is not in arrears of dues and with membership extending over at least twenty years may, by giving proper notification to the Secretary, have his dues remitted, on the understanding that he will thereafter receive the programs of the meetings but not the Bulletin and Proceedings.

Section 9. An ordinary member or a contributing member shall receive the Bulletin and Proceedings, except in the case of members whose dues are remitted under Section 8 of this Article.

Section 10. Nine dollars of the annual dues of those who receive the Bulletin and Proceedings under the provisions of this Article shall be allocated in payment therefor.

Section 11. The annual dues of ordinary and contributing members shall be due and payable at the beginning of each calendar year, at which time the Society shall submit a bill for these dues. If the annual dues of any member remain unpaid beyond a reasonable time, the Board of Trustees shall remove his name from the list of members, after due notice. If a member wishes to discontinue his membership at any time, he shall send a written resignation to the Society.

Section 12. Any member who became a life member before October 25, 1941, by the payment of a sum determined in accordance with actuarial principles shall have for life the status and privileges of an ordinary member without further payment of dues. No additional applications for life memberships will be accepted.

\section{ARTICLE X}

\section{MeEtings}

Section 1. The Annual Meeting of the Society shall be held between the fifteenth of December and the fifteenth of January next following. Notice of the time and place of this meeting shall be mailed by the Secretary or an Associate Secretary to the last known post office address of each member of the Society. The times and places of the Annual and other meetings of the Society shall be designated by the Council. No matter of general business shall be considered at any meeting of the Society except the Annual Meeting, without the recommendation of the Council.

Section 2. Meetings of the Executive Committee may be called by the President; he shall call a meeting at any time upon the written request of two of its members.

Section 3. The Council shall meet at the Annual Meeting of the Society. Special meetings of the Council may be called by the President; he shall call a special meeting at any time upon the written request of five of its members. No special meeting of the Council shall be held unless written notice of it shall have been sent to all members of the Council at least ten days before the day set for the meeting.

Section 4. The Board of Trustees shall hold its regular Annual Meeting each year between December 15 and January 20, but not before the Annual Meeting of the Society. Special meetings of the Board of Trustees may be called by the Chairman of the Board upon three days' notice of such meeting mailed to the last known post office address of each Trustee. He should call a meeting upon the receipt of a written request of two of the Trustees. Meetings for the transaction of business may also be held by common consent of all the Trustees.

Section 5. Papers intended for presentation at any meeting of the Society shall be passed upon in advance by a program committee appointed by or under the authority of the Council; and only such papers shall be presented as shall have been approved by such committee. Papers in form unsuitable for publication, if 
accepted for presentation, shall be referred to on the program as preliminary communications or reports.

\section{ARTICLE XI}

Publications

Section 1. The Society shall publish an official organ called the Bulletin of the American Mathematical Society. It shall publish two journals, known as the Transactions of the American Mathematical Society and the Proceedings of the American Mathematical Society. It shall publish a series of mathematical papers known as the Memoirs of the American Mathematical Society. The object of the Transactions, Proceedings, and Memoirs is to make known important mathematical researches. It shall publish a periodical called Mathematical Reviews, containing abstracts or reviews of current mathematical literature. It shall publish a series of volumes called Colloquium Publications which shall embody in book form new mathematical developments. It shall publish a series of monographs called Mathematical Surveys which shall furnish expositions of the principal methods and results of particular fields of mathematical research. It shall also cooperate in the conduct of the American Journal of Mathematics.

Section 2. The editorial management of the publications of the Society listed in Section 1 of this article, and the participation of the Society in the editorial management of the American Journal of Mathematics shall be in charge of the respective Editorial Committees as provided in Article III, Section 1.

\section{ARTICLE XII}

\section{AMENDMENTS}

These By-Laws may be amended or suspended at any meeting of the Society on recommendation of the Council and by a two-thirds vote of the members present, provided notice of such proposed action and of its general nature shall have been given in the call for such meeting. 